\title{
PERIPHERAL PLASMA TESTOSTERONE CONCENTRATIONS IN BULLS AROUND PUBERTY
}

\author{
M. THIBIER \\ Union Nationale des Coopératives d'Elevage et d'Insémination Artificielle, and \\ Institut National Agronomique de Paris-Grignon, 78850 Thiverval-Grignon, France
}

(Received 11th Fuly 1974)

It is now well established that dairy bulls attain their mature rate of spermatogenesis by 1 year of age (Attal \& Courot, 1963; Macmillan \& Hafs, 1968) and that gonadotrophins and steroid hormones are involved in the process of initiation and maintenance of spermatogenesis (Steinberger \& Steinberger, 1969). Already by this age, testosterone is the most important androgen secreted by the interstitial tissue (Lindner, 1969). Rawlings, Hafs \& Swanson (1972) observed an increase in the plasma levels of testosterone in five bulls up to 11 months of age and then a drop the following month. Since the levels found were highly variable, it was apparent that data from quite a large number of animals would be required to establish whether there is a significant increase or decrease in the plasma levels.

Blood samples were collected from the jugular veins of fifty-one French Friesian bulls at 9,12 and 15 months of age. The sampling period occurred over 1 year. The bulls were maintained under similar daily conditions since they were brought to the performance test station when they were 8 days old. From 9 to 15 months, the feeding regimen did not change at all and allowed a daily gain in weight of about $0.9 \mathrm{~kg}$. The bulls weighed $450 \mathrm{~kg}$ at 1 year of age. From 9 months of age, ejaculates were collected once weekly (two consecutive ejaculates) using an artificial vagina. Sperm output was monitored from 9 to 15 months of age, and the findings were used to select those bulls whose semen would be inseminated for progeny tests. The data for the semen characteristics in the present study were provided by the means of the four ejaculates (1) of the two first collections $(9 \pm 0.5$ months old), (2) of collections of 2 consecutive weeks at 12 months $( \pm 0.5)$, and (3) of the two last collections ( $15 \pm 0.5$ months old) of the control period. At 9 months, $33 \%$ of the bulls had no libido, and at 12 and 15 months, respectively, $4 \%$ and $2 \%$ of the bulls had either no libido or azoospermia when tested. The mean total number of spermatozoa per ejaculate and the percentage of motile spermatozoa are reported in Table 1. An improvement in both characteristics was observed with age. This corresponds with data which have been previously reported (Thibier \& Colchen-Bourlaud, 1972).

Plasma testosterone was determined by radioimmunoassay. The procedure used was very similar to that for progesterone and 17 $\alpha$-hydroxyprogesterone (Thibier, Castanier, Tea \& Scholler, 1973). The antiserum was raised in rabbits immunized against testosterone-3-(O-carboxy)methyloxime-BSA. The specificity and accuracy were satisfactory (Leymarie \& Scholler, 1974). 
The results, as mean \pm S.D. (coefficient of variation) in $\mathrm{ng} / \mathrm{ml}$, for the plasma testosterone concentrations of the fifty-one bulls at these three periods were: 9 months, $5.31 \pm 3.99(0.75) ; 12$ months, $4.43 \pm 3.01(0.68) ; 15$ months, $4.34 \pm 2.26$ $(0.52)$. These levels appear slightly higher than those observed by Rawlings et al. (1972) and the levels at 9 months seem to be higher than those at 12 and 15 months. Analysis of variance (Snedecor \& Cochran, 1957), however, showed that there were no significant differences between age periods or between bulls (Table 2).

The large range of testosterone concentrations at each period and in each bull is responsible of these non-significant differences. This means that even when bulls are maintained in standardized management conditions, such as those

Table 1. Semen characteristics of bulls around puberty

\begin{tabular}{c|c|c|c}
\hline $\begin{array}{c}\text { Age group } \\
\text { (months) }\end{array}$ & $\begin{array}{c}\text { No. of } \\
\text { bulls }\end{array}$ & $\begin{array}{c}\text { Total no. of spermatozoa } \\
\left(\times 10^{9}\right)\end{array}$ & $\%$ Motile spermatozoa \\
\hline 9 & 34 & $1 \cdot 13 \pm 0 \cdot 69$ & $48 \cdot 0 \pm 13 \cdot 1$ \\
12 & 49 & $2 \cdot 75 \pm 1.31$ & $60.3 \pm 16.8$ \\
15 & 50 & $3 \cdot 29 \pm 1.31$ & $63.5 \pm 15.7$ \\
\hline
\end{tabular}

Two consecutive ejaculates were collected once a week. The results are the means $\pm S . D$. of the four ejaculates collected over a 2-week period.

Table 2. Analysis of variance of plasma testosterone concentrations in bulls around puberty

\begin{tabular}{|c|c|c|c|c|c|}
\hline Source of variation & $d \cdot f$. & Sum of squares & Mean square & & $F$ \\
\hline $\begin{array}{l}\text { Total } \\
\text { Between age periods } \\
\text { Between bulls } \\
\text { Residual }\end{array}$ & $\begin{array}{r}153 \\
2 \\
50 \\
101\end{array}$ & $\begin{array}{r}1.539 \\
29 \\
606 \\
904\end{array}$ & $\begin{array}{r}14.50 \\
12.12 \\
8.95\end{array}$ & $\begin{array}{l}1.62 \\
1.35\end{array}$ & $\begin{array}{l}\text { N.S. } \\
\text { N.S. }\end{array}$ \\
\hline
\end{tabular}

N.S. $=$ Not significant $(P>0.05)$.

described above, pronounced fluctuations in blood testosterone levels occur, like those reported for adult bulls (Katongole, Naftolin \& Short, 1971), prepubertal bulls (Rawlings et al., 1972) and man (Leymarie, Roger \& Scholler, 1973). It cannot, therefore, be assumed that there is a significant increase or drop in mean testosterone concentrations around puberty in bulls. At this time, plasma testosterone concentrations were not significantly correlated with age, with the total number of spermatozoa, or with the percentage of motile spermatozoa. Hence, though both sperm production (Attal \& Courot, 1963) and sperm output in young bulls, as reported here, increase over the 6 -month period, the plasma testosterone concentration appears to be settled by 9 months of age and is independent of the characteristics of the ejaculate noted above.

We are grateful to Dr Scholler, Director of the Fondation de la Recherche en Hormonologie (Fresnes, France) for his generous gift of testosterone antiserum. 
We wish to thank Mme N. Jeanguyot and M. B. Florin for their excellent technical assistance.

\section{REFERENGES}

Atral, J. \& Gourot, M. (1963) Développement testiculaire et établissement de la spermatogénèse chez le taureau. Annls Biol. anim. Biochim. Biophys. 3, 219-241.

Katongole, C. B., Naftolin, F. \& Short, R. V. (1971) Relationship between blood levels of luteinizing hormone and testosterone in bulls and the effects of sexual stimulation. $\mathcal{F}$. Endocr. 50, $457-466$.

Leymarie, P., Roger, M. \& Scholler, R. (1973) Variations circadiennes de la testostérone plasmatique chez l'homme adulte normal. Etude par prélévements rapprochés pendant 25 heures. Annls Endocr. 34, 719-721.

LeYmarie, P. \& Scholler, R. (1974) Dosage radioimmunologique de la testostérone plasmatique chez l'adulte et l'enfant. Vérification de la spécificité par dosage en spectrométrie de masse. Annls Biol. clin. (in press).

LiNDNER, H. R. (1969) The androgenic secretion of the testis in domestic ungulates. In The Gonads, pp. 615-648. Ed. K. W. McKerns. North-Holland, Amsterdam.

Macmillan, K. L. \& Hafs, H. D. (1968) Gonadal and extra gonadal sperm numbers during reproductive development of Holstein bulls. F. Anim. Sci. 27, 697-700.

Rawlings, N. G., Hafs, H. D. \& Swanson, L. V. (1972) Testicular and blood plasma androgens in Holstein bulls from birth through puberty. F. Anim. Sci. 34, 435-440.

Snedecor, G. W. \& Gochran, W. G. (1957) Statistical Methods, 5th edn. Iowa State Gollege Press, Ames, Iowa.

Steingerger, E. \& Steingerger, A. (1969) The spermatogenic function of the testes. In The Gonads, pp. 715-737. Ed. K. W. McKerns. North-Holland, Amsterdam.

Thubier, M., Castanter, M., Tea, N. T. \& Scholler, R. (1973) Concentrations plasmatiques de la 17 $\alpha$-hydroxyprogestérone au cours du cycle de la vache. C. r. hebd. Séanc. Acad. Sci., Paris, 276, 3049-3052.

Thibier, M. \& Colchen-Bourlaud, M. A. (1972) Le choix du jeune taurillon sur sa fonction sexuelle. Elevage Insém. 127, 1-43. 